Check for updates

Cite this: RSC Adv., 2021, 11, 6517

Received 17th January 2021

Accepted 20th January 2021

DOI: $10.1039 / \mathrm{d} 1 \mathrm{ra00415h}$

rsc.li/rsc-advances

\title{
New advances on Au-magnetic organic hybrid core-shells in MRI, CT imaging, and drug delivery
}

\begin{abstract}
Fatemeh Mohajer, (D) *a Ghodsi Mohammadi Ziarani (D) *a and Alireza Badiei ${ }^{\text {b }}$
Magnetic nanoparticles have been widely studied for various scientific and technological applications such as magnetic storage media, contrast agents for magnetic resonance imaging (MRI), biolabelling, separation of biomolecules, and magnetic-targeted drug delivery. A new strategy on Au-magnetic nano-hybrid coreshells was applied in MRI, CT imaging, and drug delivery, which has been received much attention nowadays. Herein, the designing of different magnetic core-shells with Au in MRI and cancer treatment is studied.
\end{abstract}

\section{Introduction}

There are various nanoparticles for medical applications, including carbon dots ${ }^{\mathbf{1 , 2}}$ and organic core/shell nanoparticles. Among all these materials, $\mathrm{Fe}_{3} \mathrm{O}_{4}$ (ref. 3) and $\mathrm{MnFe}_{2} \mathrm{O}_{4}$ (ref. 4) gain the first step in terms of usage. However, $\mathrm{TiO}_{2},{ }^{5} \mathrm{SnO}_{2},{ }^{6} \mathrm{Ag}$, $\mathrm{Au},{ }^{8} \mathrm{~S},{ }^{9} \mathrm{BaTiO}_{3}{ }^{10}$ and $\mathrm{ZnO}^{11}$ are known for their electrical applications. Through the coating process, various materials such as polyaniline (PA), ${ }^{\mathbf{1 2}}$ polystyrene (PS), graphene,${ }^{6}$ oleic acid, polyvinylpyrrolidone (PVP), hyperbranched aromatic polyamide (HBP), ${ }^{\mathbf{1 0}}$ poly(methylmethacrylate) (PMMA), are differently used, and the provided materials are used extensively for batteries, optical sensors, and magnetic imaging. The metal-organic frameworks (MOFs) have received much attention in terms of bioimaging in living cells, as porous functional materials, which have large surface areas, high porosity, fluorescence functionalities, and good biocompatibility. Organic or inorganic fluorescent materials such as fluorescent dyes, quantum dots, and metal nanoclusters can also be applied in medicine for bioimaging.

The importance of magnetite nanoparticles $\left(\mathrm{Fe}_{3} \mathrm{O}_{4} \mathrm{NP}_{\mathrm{S}}\right)$ was extensively studied due to their many biomedical uses in cancer cells, magnetic resonance imaging (MRI) as a contrast agent, drug delivery, and hyperthermia treatment. In terms of toxicity and susceptibility, magnetite NPs are safe and have superparamagnetic applications. ${ }^{\mathbf{1 3 - 1 6}}$ For improving the stability and dispersing the NPs in water, $\mathrm{Fe}_{3} \mathrm{O}_{4} \mathrm{NP}$ was coated with $\mathrm{Au}$ NPs to improve the stability and dispersion of the NPs in aqueous media as efficient materials due to their biocompatibility, stability, resistance, which provided the potential medical requests. ${ }^{17-20}$ Gold nanoparticles (AuNPs) have received much

${ }^{a}$ Department of Physics and Chemistry, Faculty of Science, University of Alzahra, Tehran, Iran.E-mail: gmohammadi@alzahra.ac.ir; f.mohajer@alzahra.ac.ir; Fax: +98218041575

${ }^{b}$ School of Chemistry, College of Science, University of Tehran, Tehran, Iran attention because of their unique physicochemical activities such as biological, chemical, and biomedical implementations. AuNPs have been used for sensing, catalysis, imaging and diagnosis, and therapy (Fig. 1). ${ }^{21}$

Core-shell (CS) nanostructures have received much attention due to the known constituents and configuration. ${ }^{22}$ In this area, the immunization of $\mathrm{Au}$ on $\mathrm{Fe}_{3} \mathrm{O}_{4} @$ promoted the optical properties of computed tomography (CT) and MRI, which increased the resolution in $3 \mathrm{D}$ visual images in this process. ${ }^{23,24}$ Through the importance of bioimaging in living cells, metalorganic frameworks (MOFs) were used which organic or inorganic fluorescent compounds like quantum dots, fluorescent dyes, nanosheets, and metal nanoclusters can provide modified MOFs to give fluorescent nano-composites for an imaging agent. $^{25}$ In continuing our previous work, ${ }^{26,55-59}$ we decided to introduce another application of core shells, including Au-magnetic organic hybrid in MRI, CT imaging, and drug delivery.

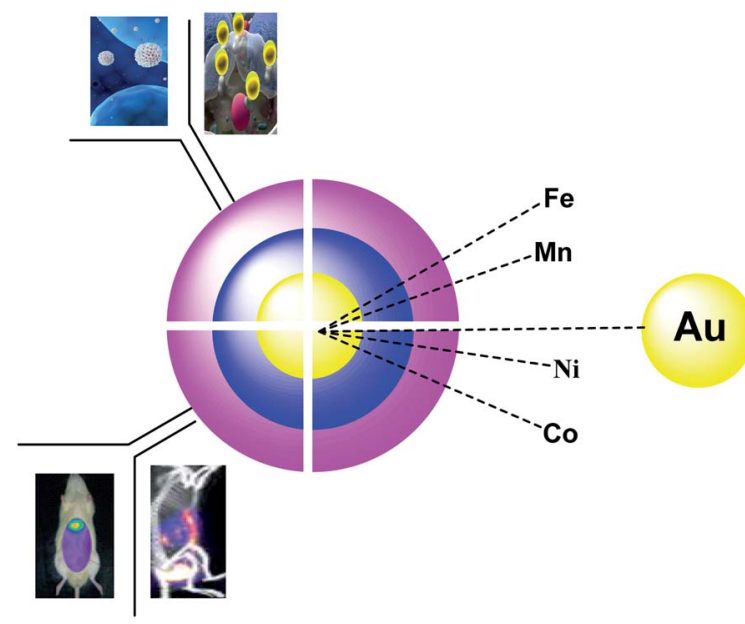

Fig. 1 The application of the different nanoparticles as core-shells. 


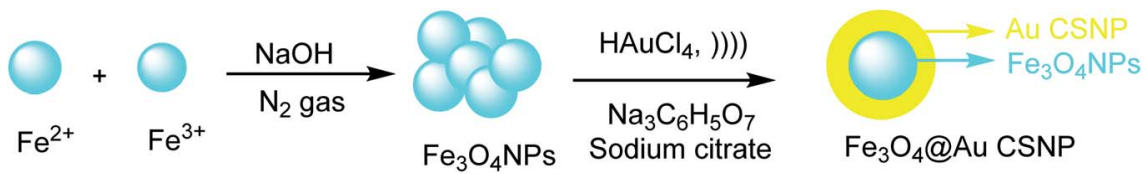

Scheme 1 The preparation of $\mathrm{Fe}_{3} \mathrm{O}_{4} @ \mathrm{aAu}$ by sonochemical method.

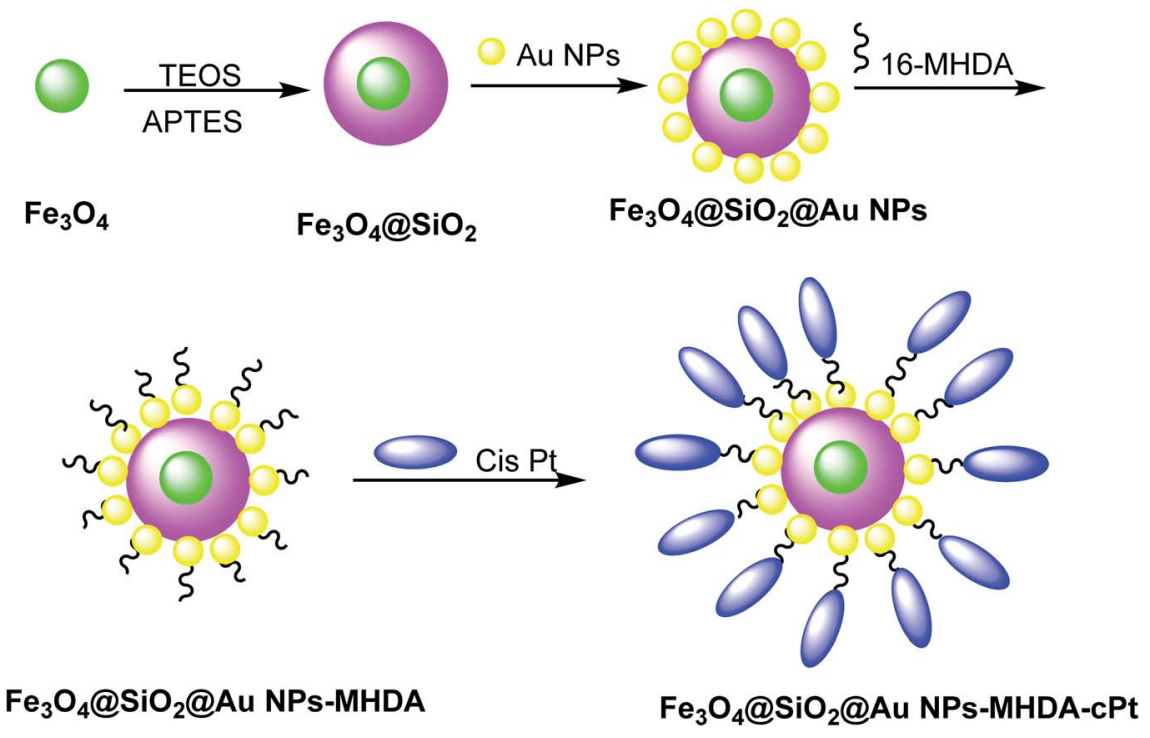

Scheme 2 The preparation of $\mathrm{Fe}_{3} \mathrm{O}_{4} \mathrm{aSiO}_{2} @ \mathrm{Au} \mathrm{NPs}-\mathrm{MHDA}-\mathrm{cPt}$.

\section{Au-magnetic organic hybrid core- shells}

\section{1. $\mathrm{Fe}_{3} \mathrm{O}_{4} @ \mathrm{SiO}_{2} @ A u$ NPs}

$\mathrm{Fe}_{3} \mathrm{O}_{4} \mathrm{NP}$ was provided by ferrous $\left(\mathrm{Fe}^{2+}\right)$ and ferric $\left(\mathrm{Fe}^{3+}\right)$ through the co-precipitation method ${ }^{27}$ with sodium hydroxide $(\mathrm{NaOH})$ under inert nitrogen gas at room temperature. To obtain the $\mathrm{Fe}_{3} \mathrm{O}_{4}$ @Au CSNPs, the $\mathrm{Fe}_{3} \mathrm{O}_{4}$ was added to the $\mathrm{HAuCl}_{4}$ solution in $\mathrm{Na}_{3} \mathrm{C}_{6} \mathrm{H}_{5} \mathrm{O}_{7}$ and sodium citrate (CS) under sonicated conditions. According to the result, $\mathrm{Fe}_{3} \mathrm{O}_{4} @ \mathrm{Au}$ CSNPs are suitable for CT and MRI imaging. The importance of this method is to give $\mathrm{Fe}_{3} \mathrm{O}_{4} @ \mathrm{Au}$ CSNPs through the rapid sonochemical synthesis (Scheme 1). ${ }^{28}$

\section{2. $\mathrm{Fe}_{3} \mathrm{O}_{4} @ \mathrm{SiO}_{2} @ \mathrm{Au} \mathrm{NPs}$}

Cisplatin (cPt) was doped on $\mathrm{Fe}_{3} \mathrm{O}_{4} @ \mathrm{SiO}_{2} @ \mathrm{Au}$ to cure cancer, which was detected through MRI images. Hydrophobic $\mathrm{Fe}_{3} \mathrm{O}_{4}$ NPs were synthesized by a thermal decomposition method ${ }^{29,30}$ using $\mathrm{FeCl}_{3} \cdot 6 \mathrm{H}_{2} \mathrm{O}$ and sodium oleate in ethanol/hexane. In the next step, $\mathrm{Fe}_{3} \mathrm{O}_{4} @ \mathrm{SiO}_{2}$ was obtained through the reverse microemulsion method. ${ }^{31}$ In this method, the mixture of Igepal CO-520 in cyclohexane and ammonium hydroxide was added to
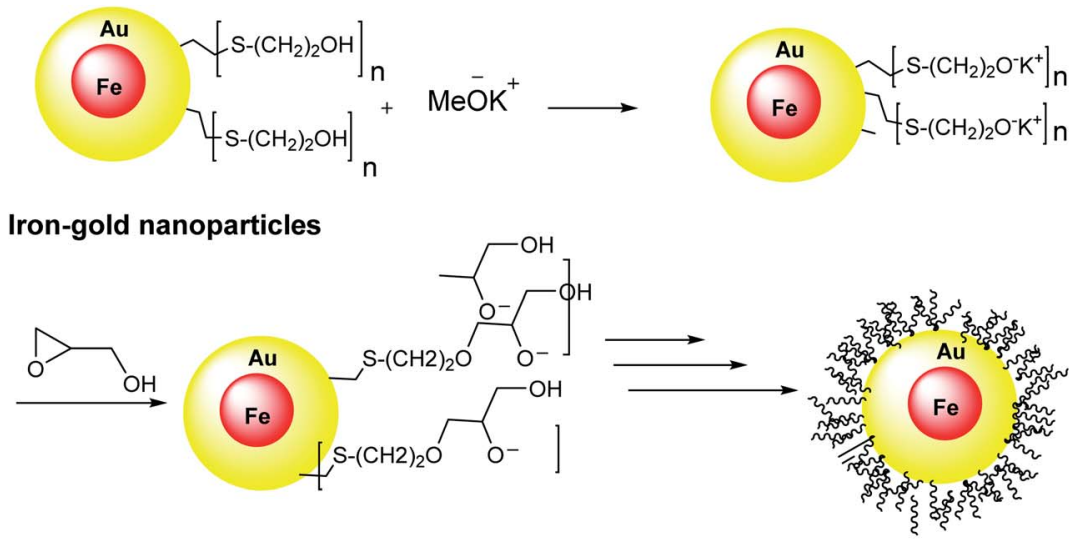

Core-shell iron-gold (Fe@Au)

Scheme 3 The preparation of core-shell iron-gold (Fe@Au). 


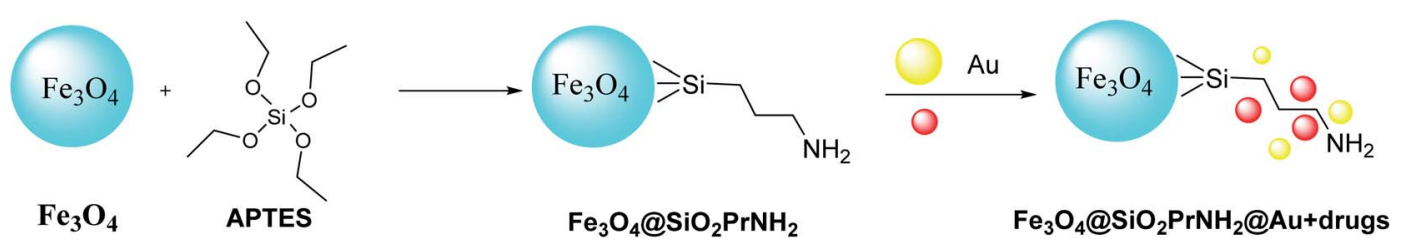

3-(4,5-dimethylthiazol-2-yl)-2,5-diphenyltetrazolium bromide $\bigcirc$

Scheme 4 The preparation of $\mathrm{Fe}_{3} \mathrm{O}_{4}\left(\mathrm{aSiO}_{2} \mathrm{PrNH}_{2} @ \mathrm{Au}+\right.$ drugs.

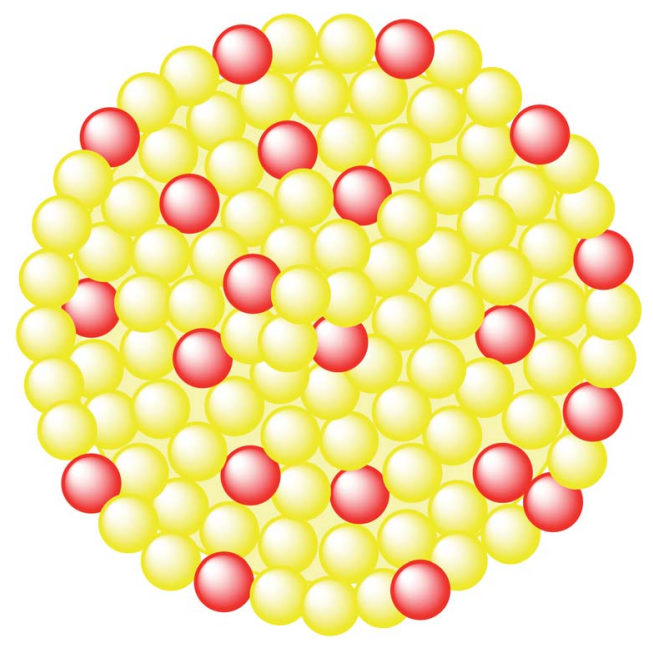

Scheme 5 The structure of designed $\mathrm{Fe}_{3} \mathrm{O}_{4} @ \mathrm{Au}$.

$\mathrm{Fe}_{3} \mathrm{O}_{4}$ NPs, followed by the addition of tetraethoxysilane (TEOS) and (3-aminopropyl)triethoxysilane (APTES) to yield $\mathrm{Fe}_{3} \mathrm{O}_{4} @$ @$\mathrm{SiO}_{2}$ core-shell nanostructures, which were added to $\mathrm{Au} \mathrm{NPs}{ }^{32}$ to obtain $\mathrm{Fe}_{3} \mathrm{O}_{4} @ \mathrm{SiO}_{2} @ \mathrm{Au} \mathrm{NPs}$. In the next step, 16-mercaptohexadecanoic acid (16-MHDA) as a linker with 16 carbon atoms containing thiol and carboxyl group was linked to the Au NPs surface and $\mathrm{cPt}$, respectively (Scheme 2). ${ }^{33}$ The functionalized $\mathrm{Fe}_{3} \mathrm{O}_{4} @ \mathrm{SiO}_{2} @ \mathrm{Au} \mathrm{NPs}$ are assessed in photothermal cancer therapy by the irradiation of two colon cancer cell lines (SW480 and SW620) with a laser $\left(\lambda=808 \mathrm{~nm}, W=100 \mathrm{~mW} \mathrm{~cm}^{-2}\right)$. It is found that laser irradiation showed the mortality of cancer cells. Because of the synergic effect of cPt and $\mathrm{Au}$ NPs and laser irradiation, the functionalized $\mathrm{Fe}_{3} \mathrm{O}_{4} @ \mathrm{SiO}_{2} @ \mathrm{Au}$ NPs are used for potential (MRI)-guided stimulated chemo-photothermal treatment of cancer.

\subsection{Core-shell iron-gold (Fe@Au)}

Core-shell iron-gold (Fe@Au) structures were used for MRI imaging and targeted drug delivery. They were obtained through the reverse micelle method. In this method, the irongold nanoparticles were coated with polyglycerol, thiol, and polymerized glycidol. Spherical core particles of iron with a thin layer of gold shell were decorated with 2-mercaptoethanol, which was linked to $\mathrm{Au}$ from $\mathrm{S}$ head to yield the $\mathrm{Au}-\mathrm{S}$ on the core-shell surfaces (Scheme 3). ${ }^{34}$

\section{4. $\mathrm{Fe}_{3} \mathrm{O}_{4} @ \mathrm{SiO}_{2} \mathrm{PrNH}_{2} @ \mathrm{Au}$}

Keshtkar et al. ${ }^{37}$ designed $\mathrm{Fe}_{3} \mathrm{O}_{4} @ A u$ by magnetic iron oxide nanoparticles through the co-precipitation process ${ }^{35}$ followed by silica according to the Stöber method ${ }^{36}$ Consequently, $\mathrm{Fe}_{3} \mathrm{O}_{4}$ nanoparticles were functionalized by (3-aminopropyl)triethoxysilane (APTES) to provide $\mathrm{Fe}_{3} \mathrm{O}_{4} @ \mathrm{SiO}_{2} \mathrm{PrNH}_{2}$, which was added to the suspension of gold nanoparticles in $\mathrm{H}_{2} \mathrm{O}$ to produce $\mathrm{Fe}_{3} \mathrm{O}_{4} @ \mathrm{SiO}_{2} \mathrm{PrNH}_{2} @ A u$. Then, 3-(4,5-dimethylthiazol-2-yl)-2,5diphenyltetrazolium bromide as human hepatocellular carcinoma was immobilized on the surface of $\mathrm{Fe}_{3} \mathrm{O}_{4} @ \mathrm{SiO}_{2}-$ $\mathrm{PrNH}_{2} @ \mathrm{Au}$ to give $\mathrm{Fe}_{3} \mathrm{O}_{4} @ \mathrm{SiO}_{2} \mathrm{PrNH}_{2} @ \mathrm{Au}+$ drugs, which was applied as MRI and CT agent (Scheme 4). $\mathrm{Fe}_{3} \mathrm{O}_{4} @ \mathrm{SiO}_{2}{ }^{-}$ $\mathrm{PrNH}_{2} @ \mathrm{Au}$ was provided through the synthetic strategy according to the laser ablation in liquid (LAL) as a green route to achieve NPs in one step (Scheme 5). ${ }^{38-41}$

\section{5. $\mathrm{Fe} / \mathrm{Fe}_{3} \mathrm{O}_{4} \mathrm{PrNH}_{2} @ \mathrm{Au}$}

Iron/iron oxide nanoparticles $\mathrm{Fe} / \mathrm{Fe}_{x} \mathrm{O}_{y} @ \mathrm{Au}$ were provided through the electric arc discharge method. Then, particles were mixed with (3-aminopropyl)trimethoxysilane (APTMS) under sonicated conditions to provide $\mathrm{Fe} / \mathrm{Fe}_{3} \mathrm{O}_{4} \mathrm{PrNH}_{2}$, which was functionalized by gold nanoparticles ${ }^{42}$ to provide $\mathrm{Fe} /$

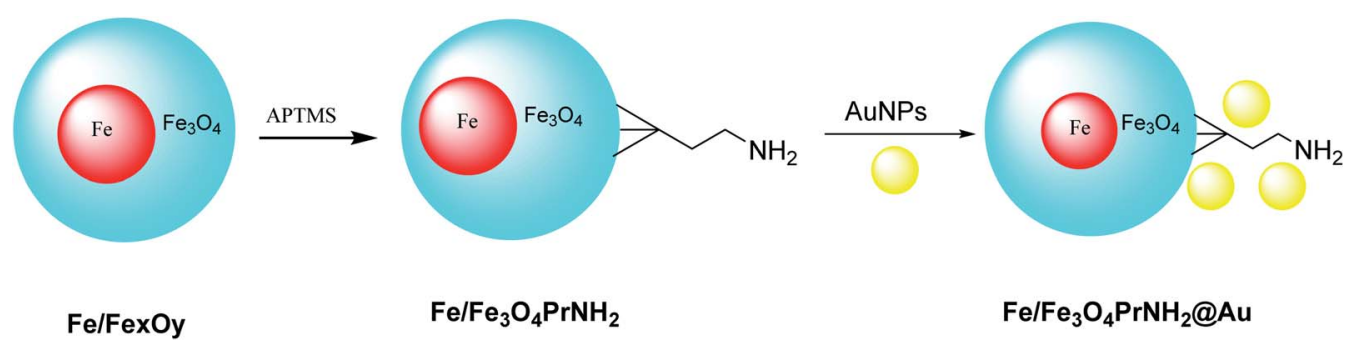

Scheme 6 The preparation $\mathrm{Fe} / \mathrm{Fe}_{3} \mathrm{O}_{4} \mathrm{PrNH}_{2} \mathrm{QAu}$ nanoparticles. 


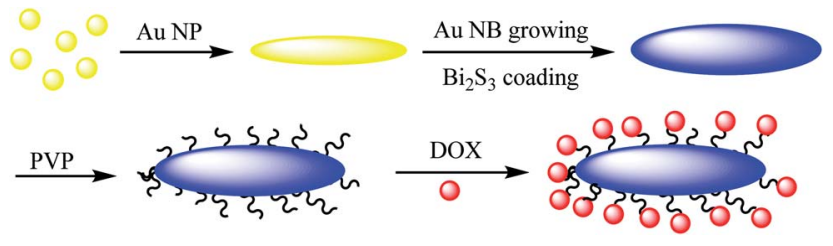

Scheme 7 The preparation of $\mathrm{NR} \mathrm{AuaBi} \mathrm{S}_{3} \mathrm{NBs}$.

$\mathrm{Fe}_{3} \mathrm{O}_{4} \mathrm{PrNH}_{2} @ \mathrm{Au}$. The designed $\mathrm{Fe} / \mathrm{Fe}_{3} \mathrm{O}_{4} \mathrm{PrNH}_{2} @ \mathrm{Au}$ nanoparticles as bifunctional magnetic plasmonic nanostructures were used in magnetic resonance imaging and magneto-optical thermal therapies (Scheme 6). ${ }^{43}$

\section{6. $\mathrm{Au} @ \mathrm{Bi}_{2} \mathrm{~S}_{3} \mathrm{NBs}$}

$\mathrm{Au} @ \mathrm{Bi}_{2} \mathrm{~S}_{3}-\mathrm{PVP}$ nano bone, which can be used as a multimodal imaging agent for PT/PA/CT image, was reported by Ouyang et $a .^{45}$ In the first step, Au NPs were synthesized ${ }^{44}$ and mixed with L-ascorbic acid (AA), hexamethylenetetramine, and thioacetamide (TAA) to give $\mathrm{Au} \mathrm{NR} \mathrm{Au} @ \mathrm{Bi}_{2} \mathrm{~S}_{3} \mathrm{NBs}$ as the theranostic agent in cancer therapy, which was added to bismuth acetate to give $\mathrm{Au} @ \mathrm{Bi}_{2} \mathrm{~S}_{3}$ core-shell NBs, followed by mixing with PVP to produce $\mathrm{Au} @ \mathrm{Bi}_{2} \mathrm{~S}_{3}-\mathrm{PVP} \mathrm{NBs}$ nano bone as an imaging agent for applying in the tumor cells (Scheme 7). The structure can be used as a nanocarrier for anticancer drugs (DOX) to be released at a special $\mathrm{pH}$.

\subsection{D-Au@Gd\&RGD}

Gold nanoparticles was provided to be functionalized by mitochondria-targeting group (Mito-S), rhodamine B derivative (RH-S), fluorescein derivative (Flu-S), tetraaza macrocyclic compounds (TAMC-S), cyclic arginine-glycine-aspartic acid peptide (cRGD-S) to yield a mono-sensitive compound. The

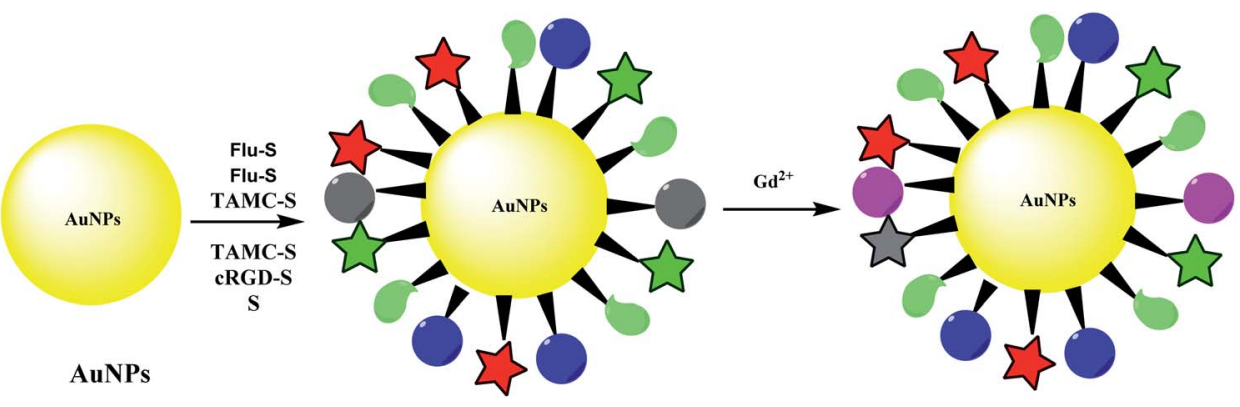

Mono-sensitive

D-Au@Gd\&RGD<smiles>CCN(CC)C1=CC2Oc3cc(N(CC)CC)ccc3C3(c4ccccc4C(=O)N3CCCC(=O)CCCCC3CCSS3)C2C=C1</smiles><smiles>O=C(O)CN(CCNC(=O)CCCCC1CCSS1)CCN1CCN(CC(=O)O)CCN(CC(=O)O)CC1</smiles><smiles>CC(C)(S)[C@H]1CC1CC1CC1</smiles><smiles>O=C(O)CN1CCN(CC(=O)O)N(CC(=O)NCCNC(=O)CCCCC2CCSS2)CC1</smiles>

Gd-S<smiles>O=C(CCCCP(c1ccccc1)(c1ccccc1)(c1ccccc1)c1ccccc1)NCCNC(=O)CCCC1CCSS1</smiles>

TAMC-S

Scheme 8 The preparation of D-Au@Gd\&RGD. 


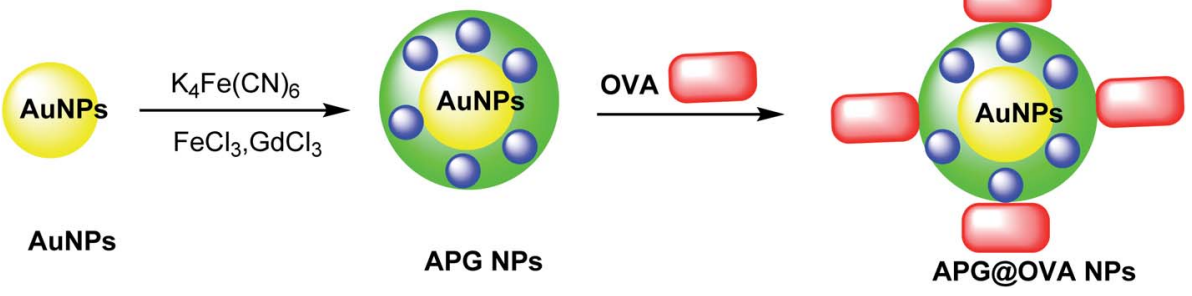

Scheme 9 The preparation of APG@OVA NPs.

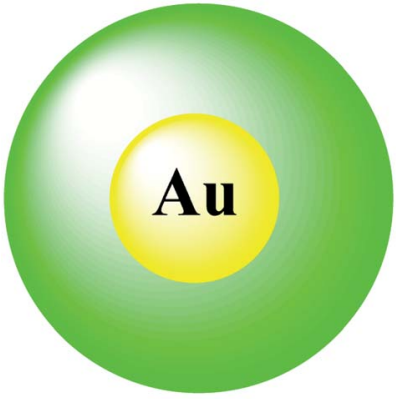

$\mathrm{Au} @ \mathrm{MnO}_{2}$

Scheme 10 The preparation of $\mathrm{Au}\left(\mathrm{MnO}_{2}\right.$.

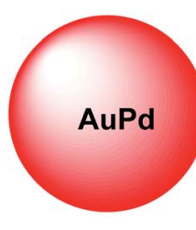

AuPd

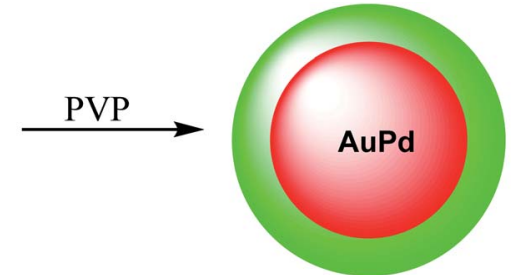

AuPd@PVP core-shell
Scheme 11 The preparation of AuPd@PVP core-shell nanoparticles.

latter was treated with $\mathrm{Gd}^{2+}$ to provide $\mathrm{D}-\mathrm{Au} @ G d \& R G D$ as the dual-sensitive structure. The application of the synthesized compound was used in MR and fluorescence imaging for a tumor in mice for tumor imaging and penetrate the bloodbrain barrier (BBB) for central nervous system (CNS) problems (Scheme 8). ${ }^{46}$

\subsection{APG@OVA NPs}

The multifunctional gadolinium-doped Au@Prussian blue nanoparticles (Au@PB-Gd@OVA) were designed as MR/SERS bimodal agents. Prussian blue nanoparticles (PB) as cyanide (CN)-bridged coordination polymer were immobilized onto the AuNP core to give a background-free surface-enhanced Raman scattering (SERS) signal. The presence of doped $\mathrm{Gd}^{3+}$ provided a sensitive agent for MRI. Through the coating of ovalbumin (OVA) physically, APG@OVA NPs were provided. ${ }^{47}$ First step: The Au NPs were prepared through the classic sodium citrate reduction process using sodium citrate and $\mathrm{HAuCl}_{4}$ solutions. Second step: $\mathrm{K}_{4}\left[\mathrm{Fe}(\mathrm{CN})_{6}\right]$ and $\mathrm{FeCl}_{3}$ were applied as the Prussian blue nanoparticles (PB) agent, which was reacted with $\mathrm{GdCl}_{3}$. These two solutions were mixed to provide APG NPs, which was added to the OVA solution to yield Au@Prussian blueGd@ovalbumin nanoparticles (APG@OVA NPs) (Scheme 9). ${ }^{48}$

\section{9. $\mathrm{Au} @ \mathrm{MnO}_{2}$}

In this study, a gold@manganese dioxide $\left(\mathrm{Au} @ \mathrm{MnO}_{2}\right)$ as coreshell structure was synthesized, which was functionalized by glutathione GSH as a theranostic agent in photoacoustic and magnetic resonance study. The GSH-triggered $\mathrm{Au} @ \mathrm{MnO}_{2}$ was applied in photoacoustic and MRI as a smart theranostic nanostructure for cancer diagnosis and treatment (Scheme 10). ${ }^{49}$

The nanostructure of AuPd@PVP is important due to their similar magnitudes to the biomolecules, which was used for in biotechnology and medicine. The chloroauric acid hydrated solution was added to the $\mathrm{Au}$ precursor; and then disodium tetrachloropalladate was mixed with ascorbic acid as a reducing agent to give AuPd (Scheme 11). ${ }^{50}$ The resulting product AuPd was mixed with polyvinyl pyrrolidone (PVP) as a surfactant to give AuPd@PVP nanoparticles for biocompatibility in vivo and in vitro study in photothermal therapy (PTT) and radiotherapy (RT). Therefore, PTT and RT could be applied for cancer therapy. The AuPd@PVP NPs have photothermal therapy (PTT) activity under NIR laser irradiation at a low power. Moreover, the NPs could be applied in radiotherapy (RT) as the sensitizer agent. Through PTT and RT, AuPd@PVP core-shell nanoparticles could be efficient for cancer therapy.

\subsection{0. $\mathrm{Fe}_{3} \mathrm{O}_{4} @ A u$}

The manganese dioxide-encapsulated gold nanoparticle (Au@ $\mathrm{MnO}_{2} \mathrm{NP}$ ) was decorated by polyethylene glycol (PEG) to provide $\mathrm{Au} @ \mathrm{MnO}_{2}-\mathrm{PEG}$ and decomposed into the naked $\mathrm{Au}$ NPs and $\mathrm{Mn}^{2+}$ in acidic media. The resulting structure was absorbed by biomolecules to give a stimuli-responsive surfaceenhanced Raman scattering (SR-SERS) nanoprobe (Scheme 12). The SR-SERS probes determined the difference between tumor and normal tissues by accuracy and even in different growth steps.

A stimulus-responsive surface-enhanced Raman scattering (SR-SERS) nanoprobe was designed to diagnose the tumor cells. The SR-SERS probes were activated by the tumor 

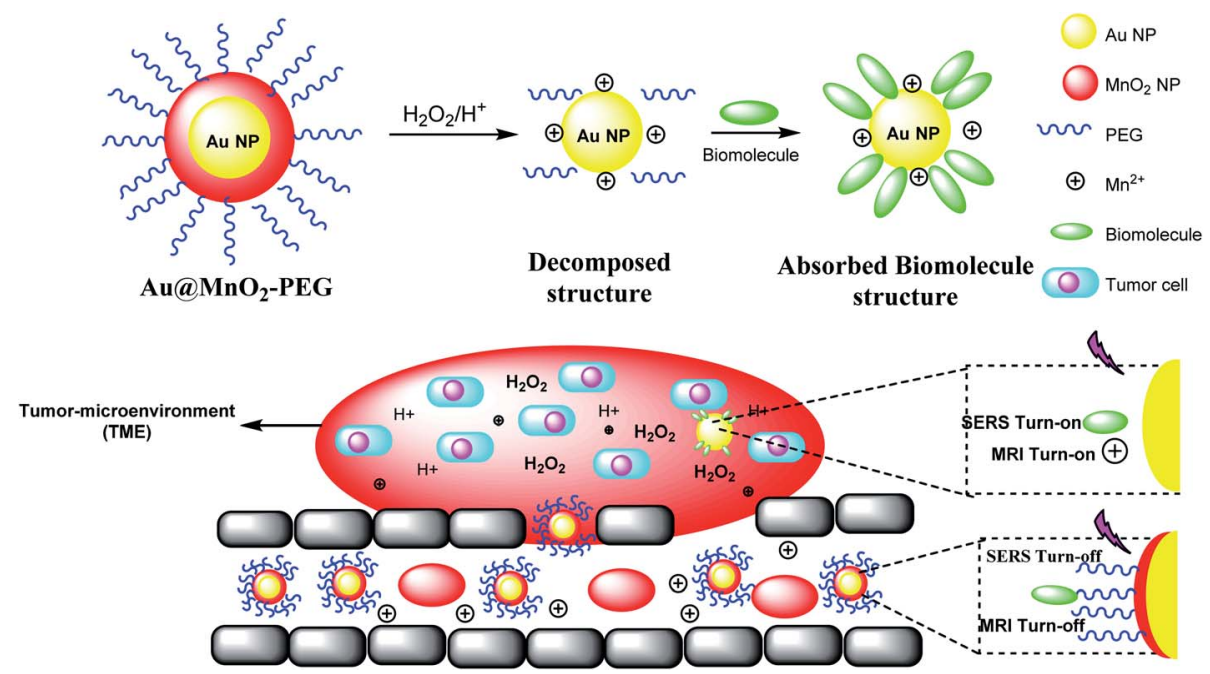

Scheme 12 The preparation of SR-SERS nanoprobe.

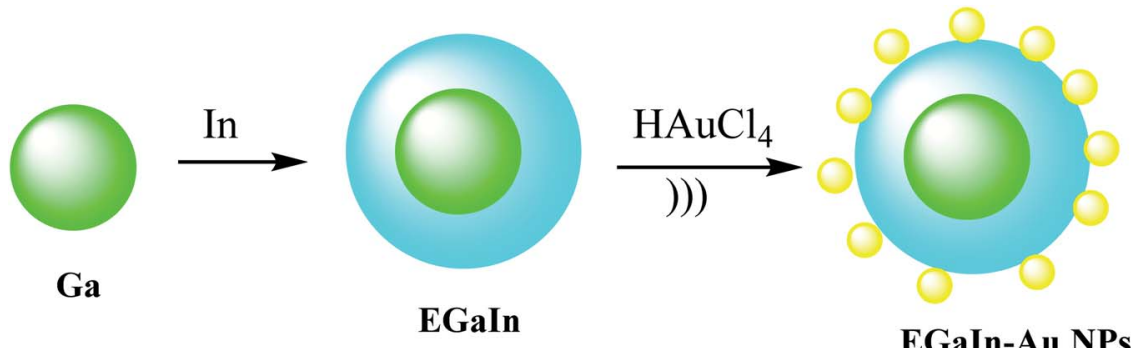

Scheme 13 The preparation of EGaln-Au NPs.

microenvironment (TME); however, in other tissues, which were highly selective to tumors, there was no activation. As a result, TME-triggered exposure with Au NPs and biomolecules could meaningfully increase; moreover, the Raman fingerprints show the complete information, compared with the traditional molecular method. The importance of the SR-SERS probes is to make a difference between tumors and healthy tissues, which might be applicable for the treatment of cancers (Scheme 12) ${ }^{46}$ In fact, $\mathrm{Au} @ \mathrm{MnO}_{2}$ nanoparticles were produced through a layer-by-layer approach. Thus, the obtained $\mathrm{Au} @ \mathrm{MnO}_{2}$-PEG nanoparticles treated with $\mathrm{H}_{2} \mathrm{O}_{2}$ in the tumor to provide $\mathrm{Mn}^{2+}$ for improving $T_{1}$-weighted $\mathrm{MR}$ imaging to create $\mathrm{O}_{2}$ for removing the cancer cells to X-rays. Therefore, Au nanoparticles increase the X-ray energy in tumor cells, and $\mathrm{MnO}_{2}$ reacts with endogenous tumor $\mathrm{H}_{2} \mathrm{O}_{2}$ to create $\mathrm{O}_{2}$ in hypoxia-associated RT resistance. Through the combination of gold nanoparticles and $\mathrm{O}_{2}$ generation by $\mathrm{MnO}_{2}$ shells, $\mathrm{Au} @ \mathrm{MnO}_{2}$-PEG core-shell nanoparticles, there is a good tumor therapeutic effect.<smiles>CC(C)[C@H]1CC1C1CC1</smiles>

Scheme 14 The preparation of core-shell I-Pd@Au-PEG-FA. 

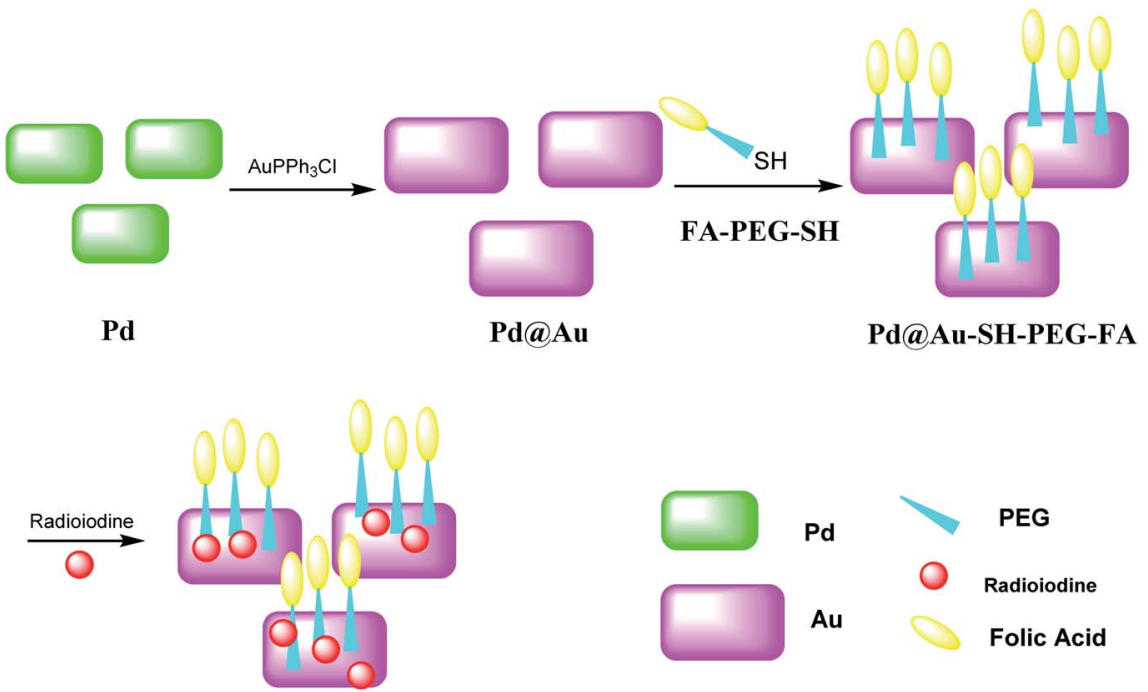

I-Pd@Au-PEG-FA

Scheme 15 The preparation of I-Pd@Au-PEG-FA nanosheets.

\subsection{EGaIn-Au NPs}

To give nano-composites through liquid metals (LM), a mixture of gallium indium-Au nanostructures (EGaIn-Au NPs) was used for providing radio-photothermal cancer treatment. In this process, Au nanodots were reduced onto the mixture of gallium indium (EGaIn) NPs surface to achieve EGaIn-Au NPs. This strategy might open a new door to a LM-based nano-composite. The EGaIn NPs were designed through the probe-sonicating method in xanthan gum solution after centrifuging the spherical EGaIn NPs, and $\mathrm{HAuCl}_{4}$ solution was mixed with EGaIn NPs for growth of Au NPs by the interfacial galvanic replacement reactions to give EGaIn-Au nano-composites (Scheme 13). ${ }^{51} \mathrm{It}$ was proved that the EGaIn-Au nano-composite was used to respond the X-ray and NIR (near-infrared laser) irradiation. The nano-composite with photothermal conversion and radiosensitization ability destroy cancer cells to cure. However, healthy tissues are damaged, they used for decreasing the growth of tumor tissues by NIR, and X-ray treatment in photothermal therapy and radiotherapy.

\subsection{I-Pd@Au-PEG-FA nanosheets}

Pd@Au-PEG-FA nanosheets were used as CT image contrast agents. The Pd@Au nanosheets were synthesized according to previous reports. ${ }^{5-54}$ FA-NHS was obtained from folic acid (FA), $N$-hydroxysuccinimide (NHS), and dicyclohexylcarbodiimide (DCC) in DMSO in the dark to provide FA-NHS, which was added to the $\mathrm{NH}_{2}-\mathrm{PEG}-\mathrm{SH}$ to provide Pd@Au-PEG-FA nanosheets, and then it was mixed with FA-PEG-SH to provide Pd@Au-PEG-FA nanosheets. Preparation of I-Pd@Au-PEG-FA nanosheets was accomplished through the reaction of Pd@AuPEG-FA with radioiodine at room temperature, which was used to load radioiodine by ${ }^{125} \mathrm{Na}^{131} \mathrm{I}$ at room temperature (Schemes 14 and 15). ${ }^{51}$ I-Pd@Au-PEG-FA nanosheets were then applied on detecting the plaques by reforming the $2 \mathrm{D}$ multifunctional structure by FA on the surface and evaluate the target specificity for the activated macrophages; the targeted probes show that 2D Pd@Au nanosheets have superior pharmacokinetic to achieve the cure effect.

\section{Conclusion}

Au nanoparticles received much attention for cancer treatment and MRI due to their high chemical stability, biocompatibility, and affinity for binding with thiol terminal groups of various organic compounds. Moreover, these mixtures give the magnetic and plasmonic properties to nanoparticles for diagnostics and therapeutic applications. However, the currently available synthesis methods for these nanoparticles are based on organic compounds.

\section{Conflicts of interest}

The authors declare that there is no declaration of competing interest in this paper.

\section{Acknowledgements}

The authors thank the research support council of Alzahra University and University of Tehran.

\section{References}

1 L. Ai, Y. Yang, B. Wang, J. Chang, Z. Tang, B. Yang and S. Lu, Sci. Bull., 2020, DOI: 10.1016/j.scib.2020.12.015.

2 Y. Xu, B. Wang, H. Zhang, X. Qu, M. Zhang, X. An, S. Lu and S. Zhang, Blood, 2019, 134, 941.

3 N. A. D. Burke, H. D. H. Stöver and F. P. Dawson, Chem. Mater., 2002, 14, 4752-4761. 
4 C. R. Vestal and Z. J. Zhang, J. Am. Chem. Soc., 2002, 124, 14312-14313.

5 A. Maliakal, H. Katz, P. M. Cotts, S. Subramoney and P. Mirau, J. Am. Chem. Soc., 2005, 127, 14655-14662.

6 Z. Du, X. Yin, M. Zhang, Q. Hao, Y. Wang and T. Wang, Mat. Lett., 2010, 64, 2076-2079.

7 T. R. Dhakal, S. R. Mishra, Z. Glenn and B. Rai, J. Nanosci. Nanotechnol., 2012, 12, 6389-6396.

8 T. Kim, H. Kang, S. Jeong, D. J. Kang, C. Lee, C.-H. Lee, M.-K. Seo, J.-Y. Lee and B. J. Kim, ACS Appl. Mater. Interfaces, 2014, 6, 16956-16965.

9 H. Chen, W. Dong, J. Ge, C. Wang, X. Wu, W. Lu and L. Chen, Sci. Rep., 2013, 3, 1910.

10 L. Xie, X. Huang, Y. Huang, K. Yang and P. Jiang, J. Phys. Chem., 2013, 117, 22525-22537.

11 P. Liu, Colloids Surf., A, 2006, 291, 155-161.

12 J. Deng, C. He, Y. Peng, J. Wang, X. Long, P. Li and A. S. C. Chan, Synth. Met., 2003, 139, 295-301.

13 P. M. Khaniabadi, D. Shahbazi-Gahrouei, A. M. S. A. Majid, M. S. Jaafar, B. M. Khaniabadi and S. Shahbazi-Gahrouei, Iran. Biomed. J., 2017, 21, 360-368.

14 H. Nosrati, M. Salehiabar, M. Fridoni, M.-A. Abdollahifar, H. K. Manjili, S. Davaran and H. Danafar, Sci. Rep., 2019, 9, 1-10.

15 M. Y. Badi, A. Azari, H. Pasalari, A. Esrafili and M. Farzadkia, J. Mol. Liq., 2018, 261, 146-154.

16 A. Mesdaghinia, A. Azari, R. N. Nodehi, K. Yaghmaeian, A. K. Bharti, S. Agarwal, V. K. Gupta and K. Sharafi, J. Mol. Liq., 2017, 233, 378-390.

17 P. M. Khaniabadi, D. Shahbazi-Gahrouei, M. S. Jaafar, A. M. S. A. Majid, B. M. Khaniabadi and S. ShahbaziGahrouei, Avicenna J. Med. Biotechnol., 2017, 9, 181-188.

18 N. Othman, P. M. Khaniabadi, M. S. Jameel, M. A. Dheyab and I. Amiri, Plasmonics, 2020, 15, 123-133.

19 M. A. Rabeea, M. N. Owaid, A. A. Aziz, M. S. Jameel and M. A. Dheyab, J. Environ. Chem. Eng., 2020, 8, 103841.

20 M. N. Owaid, M. A. Rabeea, A. A. Aziz, M. S. Jameel and M. A. Dheyab, Meas. Monit. Manag. Control, 2019, 12, 100270.

21 M. Falahati, F. Attar, M. Sharifi, A. A. Saboury, A. Salihi, F. M. Aziz, I. Kostova, C. Burda, P. Priecel and J. A. LopezSanchez, Biochim. Biophys. Acta, Gen. Subj., 2020, 1864, 129435.

22 M. Baziar, A. Azari, M. Karimaei, V. K. Gupta, S. Agarwal, K. Sharafi, M. Maroosi, N. Shariatifar and S. Dobaradaran, J. Mol. Liq., 2017, 241, 102-113.

23 D.-K. Kim, J.-W. Kim, Y.-Y. Jeong and S.-Y. Jon, Bull. Korean Chem. Soc., 2009, 30, 1855-1857.

24 J. K. Lim, S. A. Majetich and R. D. Tilton, Langmuir, 2009, 25, 13384-13393.

25 M. Liu, X. Ren, X. Meng and H. Li, Chin. J. Chem., 2020, DOI: 10.1002/cjoc.202000410.

26 G. Mohammadi Ziarani, P. Mofatehnia, F. Mohajer and A. Badiei, RSC Adv., 2020, 10, 30094-30109.

27 A. Magdalena, I. Silva, R. Marques, A. Pipi, P. Lisboa-Filho and M. Jafelicci Jr, J. Phys. Chem. Solids, 2018, 113, 5-10.
28 M. A. Dheyab, A. A. Aziz, M. S. Jameel, O. A. Noqta, P. M. Khaniabadi and B. Mehrdel, Mater. Today Commun., 2020, 25, 101368.

29 J. Park, K. An, Y. Hwang, J.-G. Park, H.-J. Noh, J.-Y. Kim, J.-H. Park, N.-M. Hwang and T. Hyeon, Nat. Mater., 2004, 3, 891-895.

30 M. V. Kovalenko, M. I. Bodnarchuk, R. T. Lechner, G. Hesser, F. Schäffler and W. Heiss, J. Am. Chem. Soc., 2007, 129, 63526353.

31 H. L. Ding, Y. X. Zhang, S. Wang, J. M. Xu, S. C. Xu and G. H. Li, Chem. Mater., 2012, 24, 4572-4580.

32 D. G. Duff, A. Baiker, I. Gameson and P. P. Edwards, Langmuir, 1993, 9, 2310-2317.

33 A. Maximenko, J. Depciuch, N. Łopuszyńska, M. Stec, Ż. Światkowska-Warkocka, V. Bayev, P. M. Zieliński, J. Baran, J. Fedotova and W. P. Węglarz, RSC Adv., 2020, 10, 26508-26520.

34 T. Jafari, A. Simchi and N. Khakpash, J. Colloid Interface Sci., 2010, 345, 64-71.

35 S. Beyaz, H. Kockar and T. Tanrisever, J. Optoelectron. Adv. M., 2009, 1, 447-450.

36 W. Stöber, A. Fink and E. Bohn, J. Colloid Interface Sci., 1968, 26, 62-69.

37 M. Keshtkar, D. Shahbazi-Gahrouei and A. Mahmoudabadi, J. Medical Signals Sens., 2020, 10, 201-207.

38 S. J. Ratnakar, T. C. Soesbe, L. L. Lumata, Q. N. Do, S. Viswanathan, C.-Y. Lin, A. D. Sherry and Z. Kovacs, J. Am. Chem. Soc., 2013, 135, 14904-14907.

39 K. Li, J.-T. Hou, J. Yang and X.-Q. Yu, ChemComm, 2017, 53, 5539-5541.

40 L.-L. Li, K. Li, M.-Y. Li, L. Shi, Y.-H. Liu, H. Zhang, S.-L. Pan, N. Wang, Q. Zhou and X.-Q. Yu, Anal. Chem., 2018, 90, 58735878.

41 V. Torresan, D. Forrer, A. Guadagnini, D. Badocco, P. Pastore, M. Casarin, A. Selloni, D. Coral, M. Ceolin and M. B. Fernández van Raap, ACS Nano, 2020, 14, 12840-12853.

42 S. L. Westcott, S. J. Oldenburg, T. R. Lee and N. J. Halas, Langmuir, 1998, 14, 5396-5401.

43 E. Kheradmand, R. Poursalehi and H. Delavari, Appl. Nanosci., 2020, 10, 1083-1094.

44 X. Ye, L. Jin, H. Caglayan, J. Chen, G. Xing, C. Zheng, V. Doan-Nguyen, Y. Kang, N. Engheta, C. R. Kagan and C. B. Murray, ACS Nano, 2012, 6, 2804-2817.

45 R. Ouyang, P. Cao, P. Jia, H. Wang, T. Zong, C. Dai, J. Yuan, Y. Li, D. Sun, N. Guo, Y. Miao and S. Zhou, Bioact. Mater., 2021, 6, 386-403.

46 C. Zhang, X. Cui, J. Yang, X. Shao, Y. Zhang and D. Liu, Chem. Sci., 2020, 6111-6120.

47 C. Zhang, Z. Xu, H. Di, E. Zeng, Y. Jiang and D. Liu, Theranostics, 2020, 10, 6061-6071.

48 Y. Li, C. H. Li and D. R. Talham, Nanoscale, 2015, 7, 52095216.

49 H. Wang, L. An, C. Tao, Z. Ling, J. Lin, Q. Tian and S. Yang, Nanoscale, 2020, 12, 5139-5150.

50 Y. Xiang, X. Peng, X. Kong, Z. Tang and H. Quan, Colloids Surf., A, 2020, 124652. 
51 Z. Guo, L. Yang, M. Chen, X. Wen, H. Liu, J. Li, D. Xu, Y. An, C. Shi, J. Li, X. Su, Z. Li, T. Liu, R. Zhuang, N. Zheng, H. Zhu and X. Zhang, Nano Res., 2020, 13, 173-182.

52 M. Chen, S. Tang, Z. Guo, X. Wang, S. Mo, X. Huang, G. Liu and N. Zheng, Adv. Mater., 2014, 26, 8210-8216.

53 M. Chen, Z. Guo, Q. Chen, J. Wei, J. Li, C. Shi, D. Xu, D. Zhou, X. Zhang and N. Zheng, Sci. Adv. Mater., 2018, 9, 4268-4274. 54 Z. Guo, M. Chen, C. Peng, S. Mo, C. Shi, G. Fu, X. Wen, R. Zhuang, X. Su and T. Liu, Biomaterials, 2018, 179, 134143.
55 V. Fathi Vavsari, G. Mohammadi Ziarani and A. Badiei, RSC Adv., 2015, 5(111), 91686-91707.

56 G. Mohammadi Ziarani, M. Malmir, N. Lashgari and A. Badiei, RSC Adv., 2019, 9(43), 25094-25106.

57 G. Mohammadi Ziarani, Z. Hassanzadeh, P. Gholamzadeh and S. Asadi, RSC Adv., 2016, 6(26), 21979-22006.

58 M. Mehdi, A. Badiei and G. Mohammadi Ziarani, RSC Adv., 2015, 5(46), 36530-36539.

59 G. Mohammadi Ziarani, S. Rohani, A. Badiei and A. Ziarati, RSC Adv., 2018, 8, 41048-41100. 